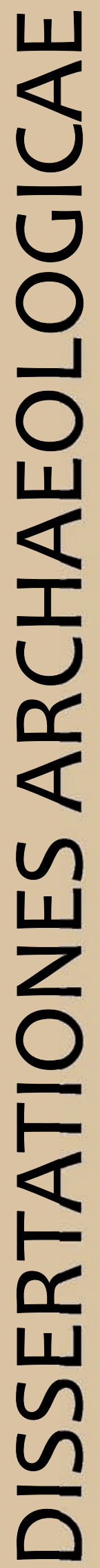

ex Instituto Archaeologico Universitatis de Rolando Eötvös nominatae

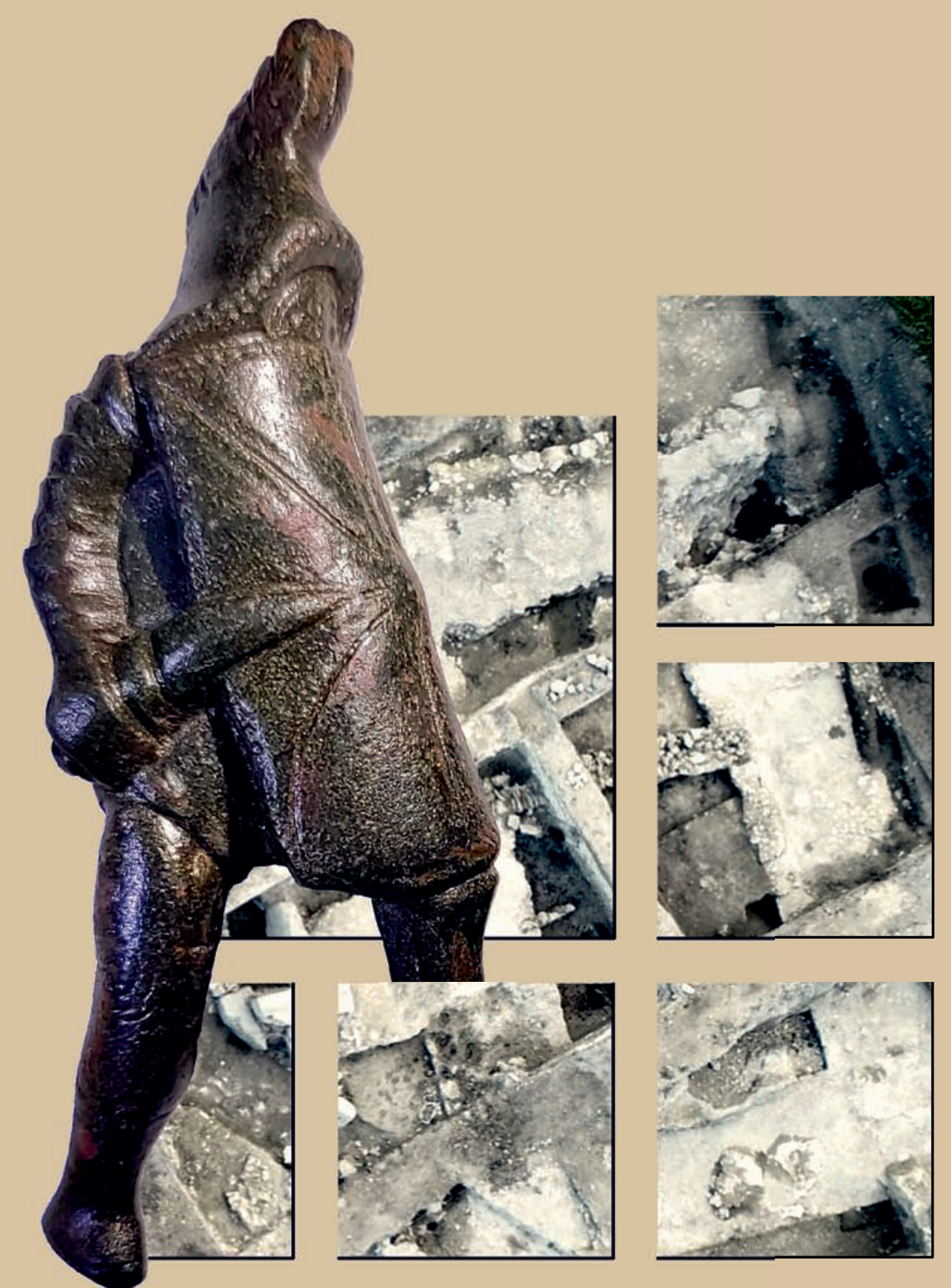

$$
\text { Ser. 3. No. 7. } 2019
$$




\section{Dissertationes Archaeologicae ex Instituto Archaeologico}

Universitatis de Rolando Eötvös nominatae Ser. 3. No. 7.

Budapest 2019 
Dissertationes Archaeologicae ex Instituto Archaeologico Universitatis de Rolando Eötvös nominatae

Ser. 3. No. 7.

Editor-in-chief:

DÁvid BARTUS

Editorial board:

LÁsZló BARTOSIEWICZ

LÁSZLÓ BORHY

ZOLTÁN CZAJLIK

IsTVÁN FELD

GÁBOR KALLA

PÁL RACZKY

MikLÓs SzABÓ

TivadAR VidA

Technical editor:

GÁBOR VÁCZI

Proofreading:

SZILVIA BARTUS-SZÖLLősI

ZsóFIA KondÉ

Aviable online at http://dissarch.elte.hu

Contact: dissarch@btk.elte.hu

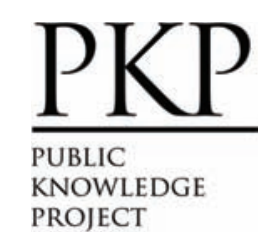

๑ ELTE Eötvös Loránd University, Institute of Archaeological Sciences

Layout and cover design: Gábor Váczi

Budapest 2019 


\section{CONTENTs}

\section{ARticles}

János Gábor TARBAY

The Casting Mould and the Wetland Find - New Data on the Late Bronze Age

Peschiera Daggers

Máté MeRvel

Late Bronze Age stamp-seals with negative impressions of seeds from Eastern Hungary

János Gábor TARBAY

Melted Swords and Broken Metal Vessels - A Late Bronze Age Assemblage

from Tatabánya-Bánhida and the Selection of Melted Bronzes

Ágnes ScHNEIDER

Multivariate Statistical Analysis of Archaeological Contexts: the case study

of the Early La Tène Cemetery of Szentlörinc, Hungary

Csilla SÁRÓ - Gábor LASSÁNYI

Bow-tie shaped fibulae from the cemetery of Budapest/Aquincum-Graphisoft Park

Dávid BARTus

Roman bronze gladiators - A new figurine of a murmillo from Brigetio

Kata DÉvAI

Re-Used Glass Fragments from Intercisa

Bence Simon

Rural Society, Agriculture and Settlement Territory in the Roman, Medieval and Modern Period Pilis Landscape

Rita RAKONCZAY

„Habaner“ Ofenkacheln auf der Burg Čabrad”

\section{FIELD REPORT}

Bence Simon - Anita Benes - Szilvia Joháczi - Ferenc BARnA

New excavation of the Roman Age settlement at Budapest dist. XVII, Péceli út (15127) site 


\section{Thesis Abstracts}

Kata SzILÁGYi

Die Silexproduktion im Kontext der Südosttransdanubischen Gruppe

der spätneolithischen Lengyel-Kultur

Norbert FARAGÓ

Complex, household-based analysis of the stone tools of Polgár-Csőszhalom

János Gábor TARBAY

Type Gyermely Hoards and Their Dating - A Supplemented Thesis Abstract

Zoltán Havas

The brick architecture of the governor's palace in Aquincum

Szabina Merva

'...circa Danubium...' from the Late Avar Age until the Early Árpádian Age-

$8^{\text {th }}-11^{\text {th }}$-Century Settlements in the Region of the Central Part of the Hungarian

Little Plain and the Danube Bend

Szabolcs Balázs NAGY

Noble Residences in the $15^{\text {th }}$ century Hungarian Kingdom - The Castles of Várpalota,

Ujlak and Kisnána in the Light of Architectural Prestige Representation

Ágnes KollátH

Tipology and Chronology of the early modern pottery in Buda 


\title{
Re-Used Glass Fragments from Intercisa ${ }^{1}$
}

KATA DÉvaI

Hungarian Academy of Sciences,

ELTE Eötvös Loránd University

kata.devai@gmail.com

\begin{abstract}
Re-worked glass objects are known all over the Roman Empire, but detailed analysis of various types of re-working sherds have not yet been undertaken. In the following study, I give some examples of some interesting uses from Intercisa.

The over thirty re-used glass vessel fragments from Intercisa are noteworthy since they come from the find material of a single vicus. It seems likely that the repurposing of broken glass vessels was a more common practice than the currently available publications would suggest. In all likelihood, it made good sense to re-use the fragments of broken glass vessels either as simple domestic objects or as grave goods.
\end{abstract}

A few years ago, I published a study on the glass vessel fragments from Aquincum, which clearly bore traces of secondary re-use. ${ }^{2}$ Here, I shall present and discuss similar finds from Intercisa, whose form resembles the pieces from Aquincum, while their function differed considerably.

After a glass vessel broke, the sharp, jagged edges were carefully trimmed off. As Sylvia Fünfschilling noted, this secondary working of broken glass vessels was undoubtedly undertaken with a definite purpose in mind. ${ }^{3}$ The careful trimming and smoothing of the edges can be clearly made out: comparing these pieces with other broken glass vessels, it is quite obvious that the base of a glass vessel cannot break off without retaining a single jagged and sharp edge of the vessel wall (Fig. 10.1,3).

Although re-worked glass shards are known from the entire territory of the Roman Empire, comprehensive and detailed studies on the re-worked fragments are still largely lacking. Sylvia Fünfschilling devoted a study to the broken glass fragments bearing traces of re-working from Augusta Raurica. ${ }^{4}$ No such study has yet been undertaken for the glass fragments from Pannonia.

The glass fragments recovered from burials in Aquincum shed light on an interesting burial custom. In some graves, the separately blown base rings of glass vessels were deposited beside the legs of the interred individuals. These objects were originally separately blown and possibly came from pitchers, although they could also have been parts of larger deep bowls.

1 This study is part of my research project funded by the Premium postdoctoral fellowship program of the Hungarian Academy of Sciences, host institution: ELTE Eötvös Loránd University. Working title of the project: "Glass vessels in Pannonia - everyday usage and production from 1st to 3rd century AD"; ID number: 462032.

2 DÉvai 2016.

3 FÜNFSCHILLING 2015, 170.

4 FÜNFSCHILLING 2015, 170-177. 


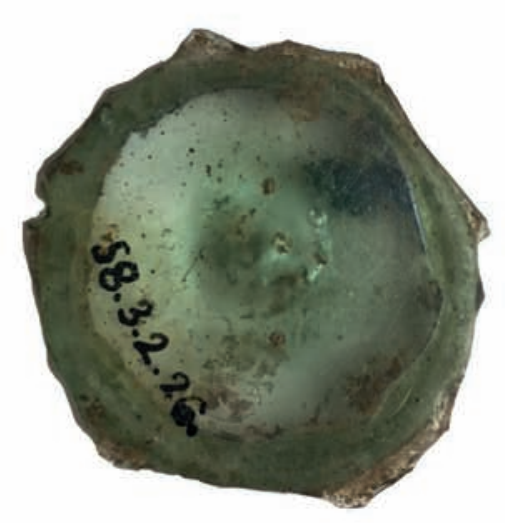

1

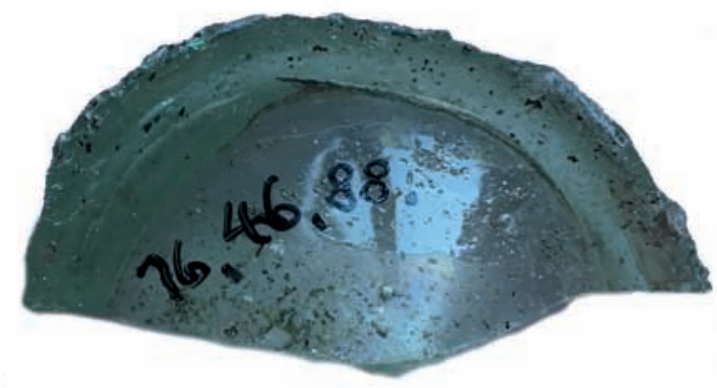

4

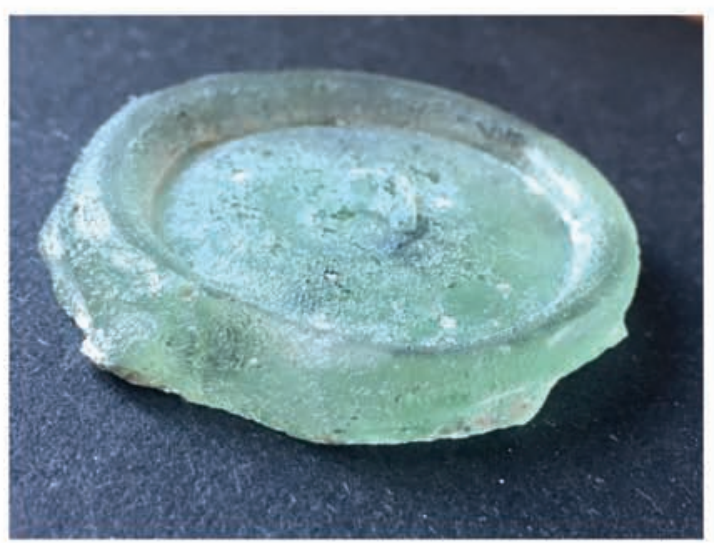

6

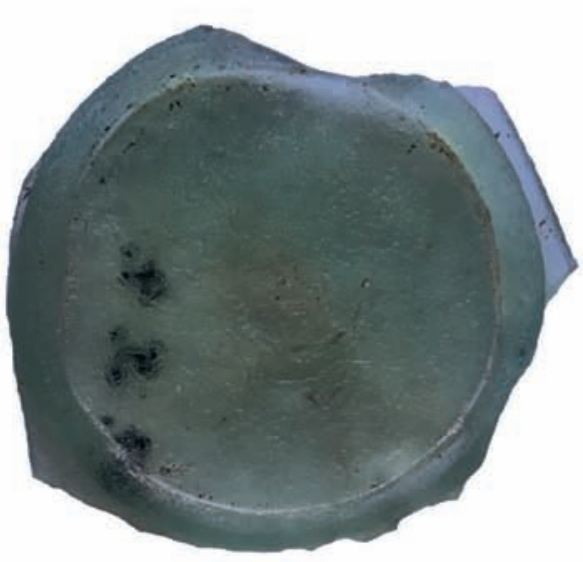

8

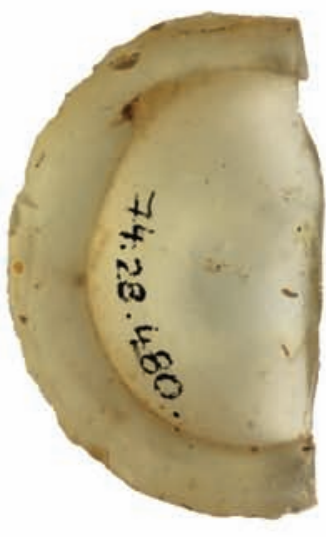

2

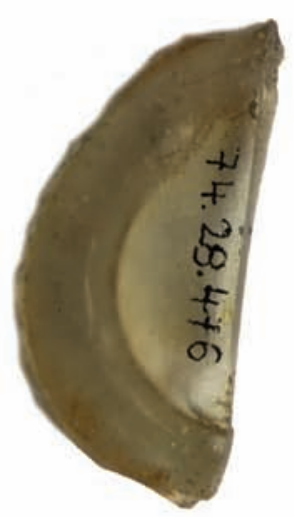

3

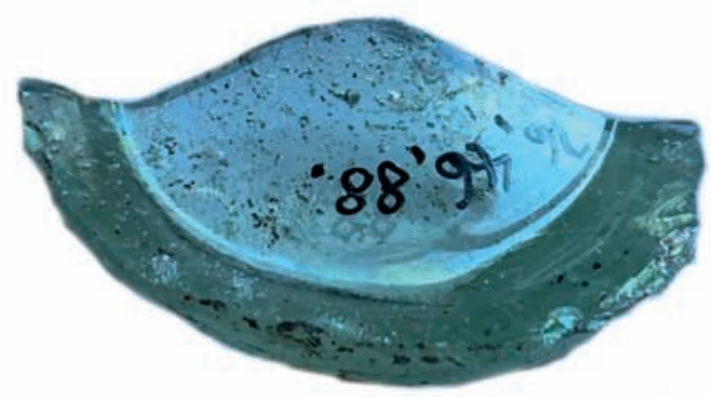

5

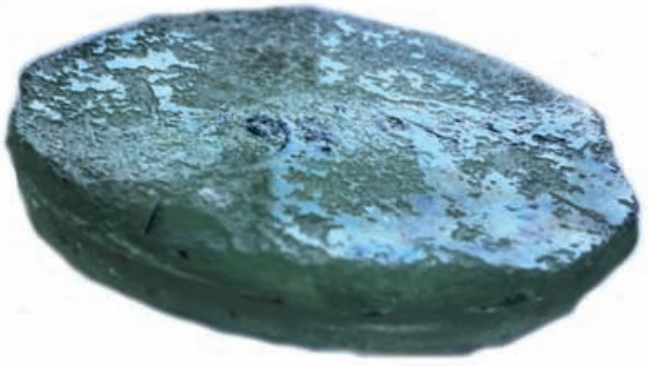

7

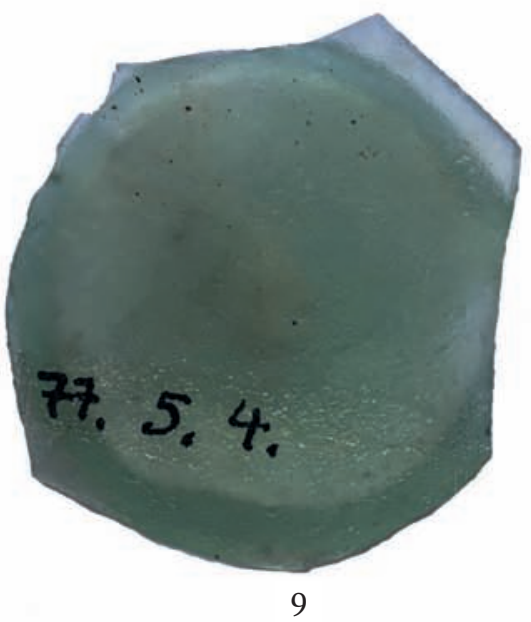

Fig. 1. Re-Used Glass Fragments from Intercisa. 
Since the vessel walls are missing, the forms of the original vessels remain uncertain. What seems certain is that they did not all belong to the same category, which is immediately apparent from the sizes of the rings, which are roughly similar, but not identical. Despite the careful excavation of the graves, other, similarly thick glass fragments - e.g. of jug handles or jug rims - were not found, even though these should otherwise have been relatively better preserved. It would appear that the vessel walls were carefully trimmed off from the base rings, on which no sharp edges were left, even though they bear no obvious signs of grinding/ polishing either. The mode of their deposition is also quite typical: they were placed in the graves upside down, which clearly suggests that they were intended as grave offerings, to serve as replacements for glass cups. ${ }^{5}$

The occurrence of such finds was first noted by Paula Zsidi in her report on the excavation of the Kaszásdűlő-Raktárrét cemetery. Base rings were found in three burials (Graves 230, 275 and 294), described by P. Zsidi as follows: "As for cups, the following three vessels can be mentioned, all of which were originally the base parts of larger, apparently more ornate vessels; when the upper parts became damaged, the bases could be still used as cups. Apparently, an effort was made to make them safe for use by trimming the sharp edges of the base."

In her study on re-worked glass fragments, S. Fünfschilling identified various categories and sought to determine their possible new function. ${ }^{7}$ The most often re-used pieces came from vessel base rings, generally representing the following types: folded tubular base rings, disclike folded bases (IsINGs 109) or applied base rings (such as IsINGs 85), which fall into a wide range of sizes.

One new function has already been mentioned in the above: it seemed practical to use the base of larger broken vessels after trimming off the jagged edges for funerary purposes, as cups or bowls deposited in burials. However, they could also be repurposed as small cups, bowls or even cosmetics palettes in daily life.

However, there also wide flat base rings that would have been unsuitable for use as cups. S. Fünfschilling suggested a possible function as vessel lids, with the broken, trimmed break on the inner side fitted to the other vessel's rim, where its rough surface would have been out of the way, while the base ring itself would have provided a comfortable grip. Obviously, it is near-impossible to document this conceivable usage in archaeological contexts; however, one experiment convincingly demonstrated that when fitted onto the rim of various ceramic vessels and cups, the re-worked base rings often matched exactly the mouth dimensions. ${ }^{8}$ Glass base rings were particularly convenient for use as lids covering various vessels because they could be easily cleaned, while their weight ensured an exact and tight fit onto the vessel mouths. Glass fermentation weights are still used when pickling vegetables and fruits, which prevent mould caused by fermentation gases from forming on them. Given their weight, glass discs and base rings would have been highly suited to this use in the Roman period too.

Another option can also be considered in the case of smaller applied ring base fragments (measuring 4-6 cm in diameter), to which an analogy is provided by the pottery counters

5 DÉvai 2016, 135.

6 Zsidi 1984, 250.

7 FÜNFSCHILLING 2015, 170-177.

8 FÜNFSCHILLING 2015, 170. 
made from broken vessel walls since their size and form resemble the discs made from glass vessel bases. Grey and yellowish pottery sherds were frequently fashioned into discs with a diameter of 4-6 cm. Several pieces usually come to light each year at Brigetio. N. Crummy distinguished four groups based on their size and shape. ${ }^{9}$ The size of pottery counters ranges from 17 to $55 \mathrm{~mm}$. Thus far, there is little in the way of archaeological evidence of what they were used for, although they seem to be items of common use in most households and may therefore have had a domestic purpose..$^{10}$ One possibility is that these roundels with their great range of sizes were household weights, used probably in the kitchen. Another interesting suggestion is that the larger pieces might have been lids for narrow-necked jars in which dry goods were stored. ${ }^{11}$ Another possible function for large roundels could have been their use as hot pads onto which pots hot from the fire or oven were set. ${ }^{12}$ Alternately, some may have been used as reckoning counters. ${ }^{13}$ Yet another possibility that has been considered is that some of the larger counters were used in a game involving throwing, ${ }^{14}$ which is supported by the counters' abraded surfaces. Their most likely use was probably as gaming pieces, even though their sizes have a fairly wide range (ranging from 17 to $55 \mathrm{~mm}$ ), which might seem rather large at first sight for board games; however, we should entertain the possibility that they were used not only in "classical" board games, but also on a larger board drawn on the ground, or that larger pieces had a greater value than smaller ones. ${ }^{15}$

As we can see, there is no one single explanation for the possible function(s) of these counters; however, what is relevant for us here is that the size and form of pottery counters as well as the fact that they were made from broken pottery sherds have much in common with some of the re-worked glass base rings, particularly the applied base rings and the simple flat tubular base rings. The high degree of similarity raises the possibility that some may have served similar purposes, namely that a part of the flat disc-shaped glass base rings with a diameter of around 40-50 mm had likewise been used as gaming pieces in board games, while others functioned as stoppers for narrow-mouthed flasks.

Their use as counters/gaming pieces seems quite feasible, given that counters made from broken glass recycled domestically were widespread in the Roman world. Counters generally have a plano-convex discoid shape with a flat base, a convex top and rounded edge. Their colour varies: opaque black and white pieces occur frequently alongside green translucent exemplars (Fig. 10.2). Counters are divided into two main groups, with the smaller ones $(10-20 \mathrm{~mm})$ most likely used as counter pieces or calculi with a portable counting board, abacus or quinarius, and the larger ones $(27-32 \mathrm{~mm})$ serving as gaming piece or oculi. ${ }^{16} \mathrm{It}$ would hardy be surprising, then, if in addition to the glass counters and gaming pieces made from remelted broken glass shards,${ }^{17}$ base rings from broken vessels had also been used for this purpose.

9 Crummi 1983, 93.

10 Crummy 1983, 93.

11 Crummy 1983, 93; MacGregor 1978, 33.

12 AdDyman - Priestley 1977, 139.

13 Crummy 1983, 93; MacGregor 1978, 33.

14 Crummy 1983, 94.

15 Crummy 1983, 94.

16 Price 1985, 214; Cosyns 2016, 200.

17 Pliny NH, XXXVI, 199. 


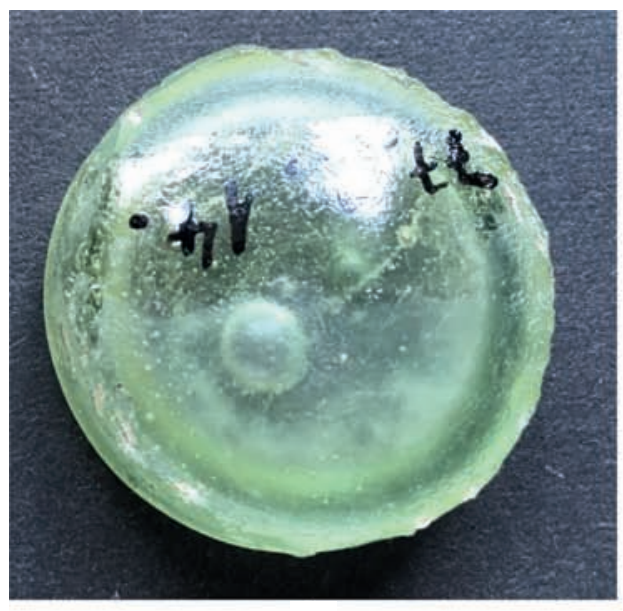

1

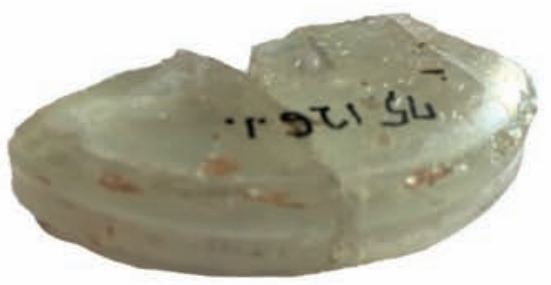

3

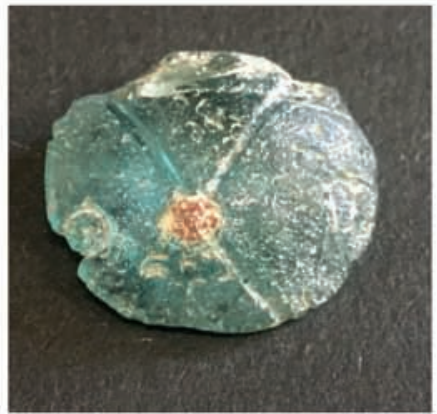

4

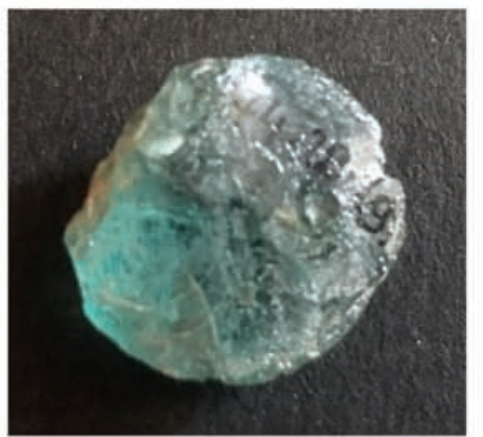

5

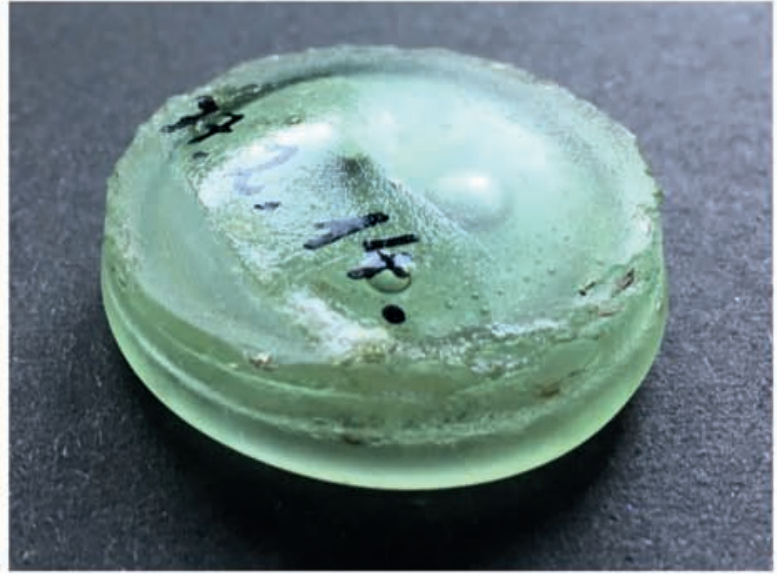

2

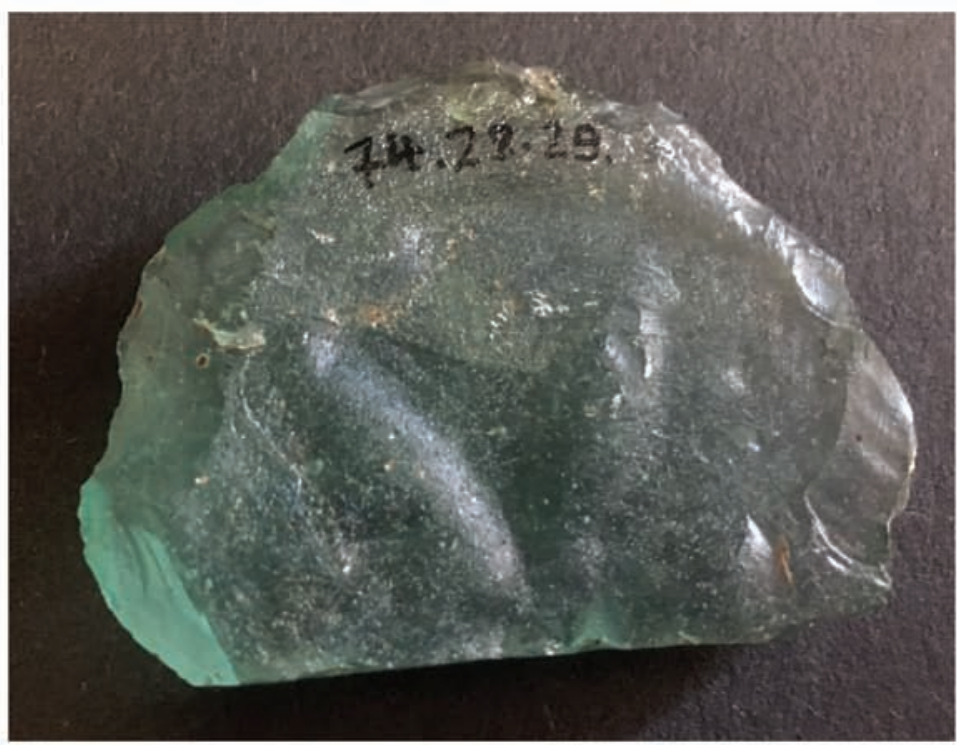

6

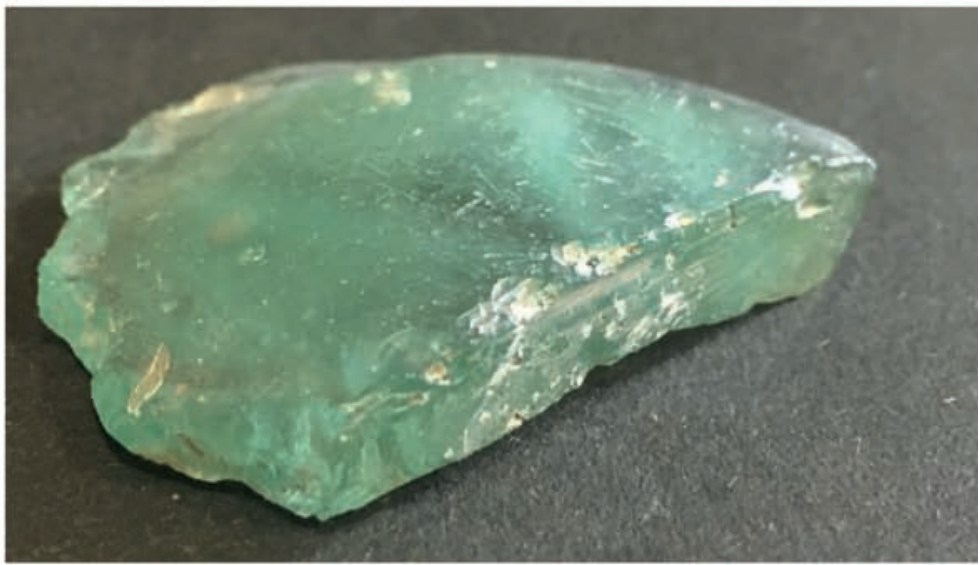

$1 \mathrm{~cm}$

7

Fig. 2. Re-Used Glass Fragments from Intercisa. 


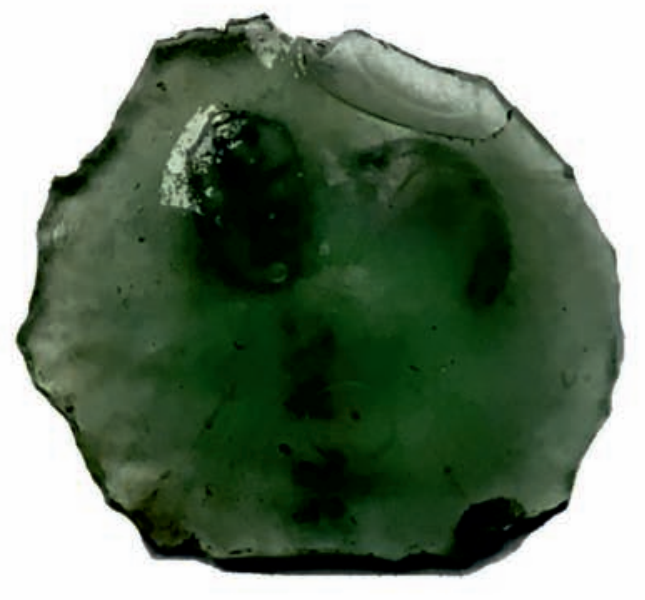

1

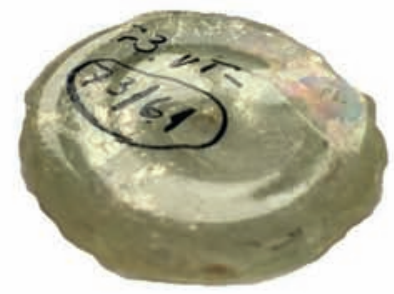

3
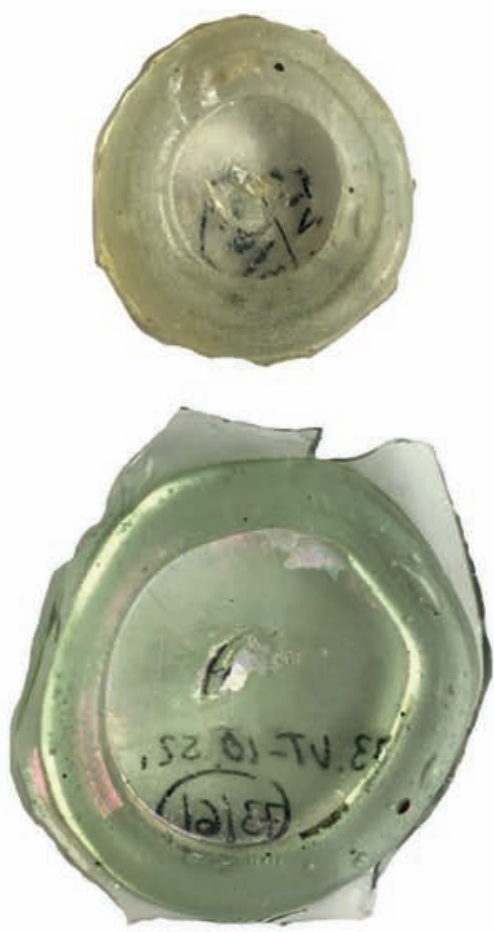

5-6
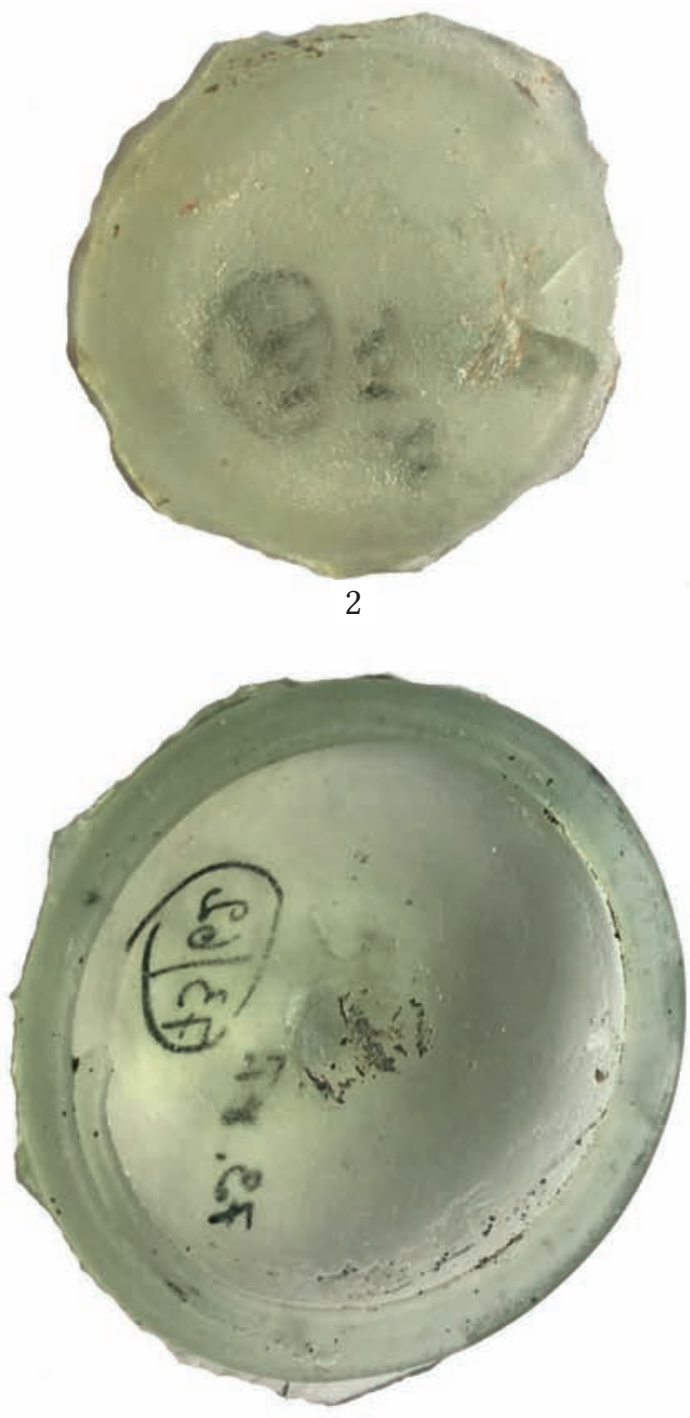

4

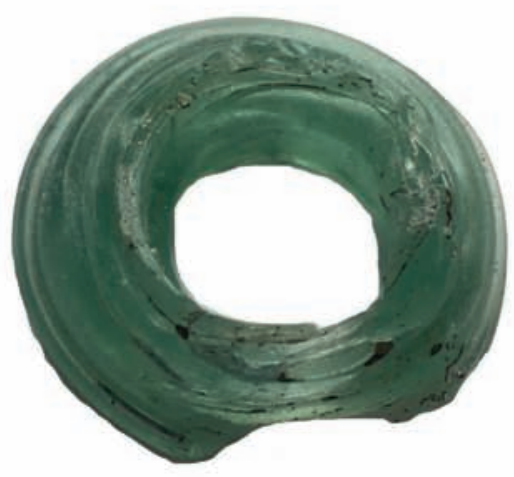

7

$1 \mathrm{~cm}$

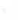

Fig. 3. Re-Used Glass Fragments from Intercisa. 


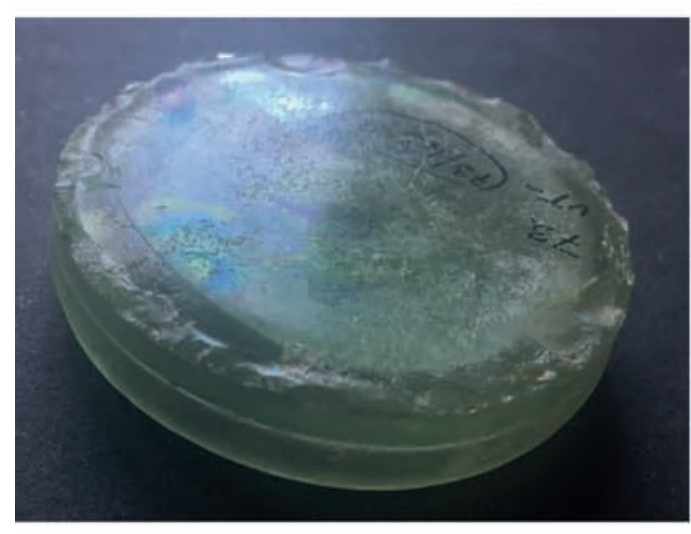

1

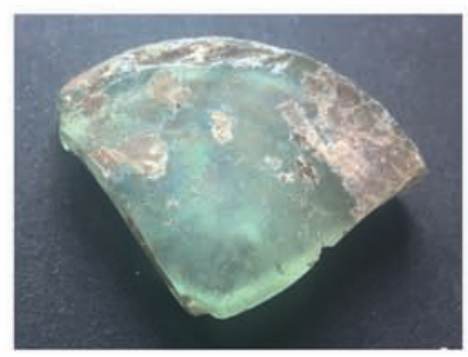

3

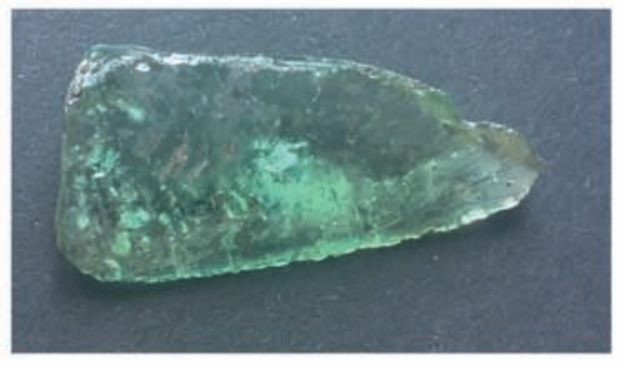

5

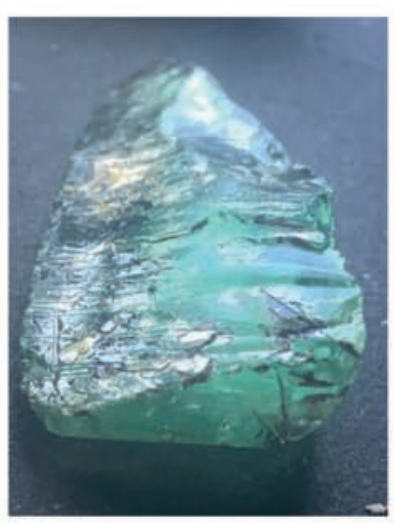

7

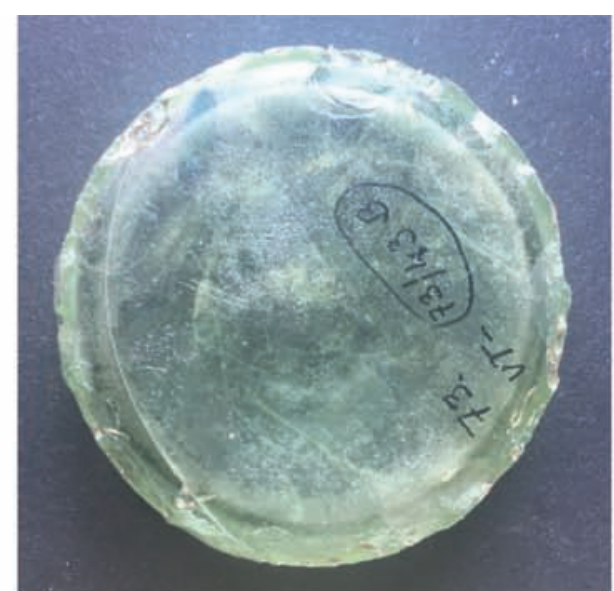

2

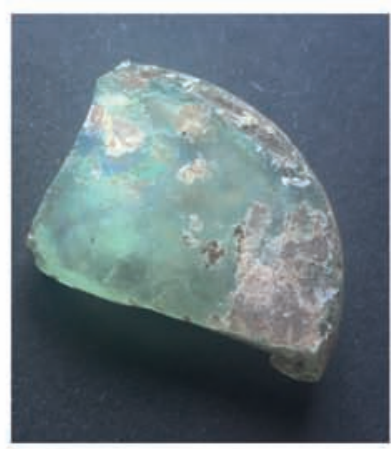

4

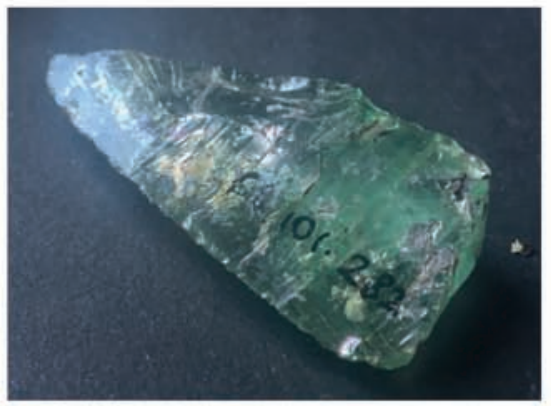

6

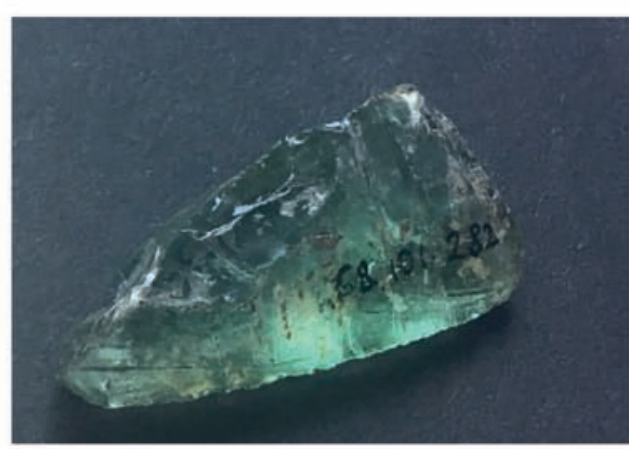

8

Fig. 4. Re-Used Glass Fragments from Intercisa. 
Aside from base rings, the second most common practice for recycling broken glass was the re-use of flat shards, either from a flat vessel part or the fragments of glass panes These often have regular geometric forms such as triangles or squares. The function of these pieces is still unclear: they may have been inlays for decorating furniture or jewellery, or again, gaming pieces for board games. Four small square shards with reworked edges, possibly part of some piece of jewellery, were recovered from a burial in Saintes. ${ }^{18}$ A glass shard used as a decorative inlay is known from Pannonia too: a diadem inlaid with a glass shard was deposited in a child's burial in Sopianae dating from the late Roman period. ${ }^{19} \mathrm{~S}$. Fünfschilling mentions pieces that were reworked to create a cutting edge. The function of these pieces still eludes us: they may have been used during textile or leather working. ${ }^{20}$

In the following, I shall describe a few fragments from Intercisa on which traces of re-working can be clearly identified, followed by a discussion of their possible function. Most of the pieces in question came to light in the vicus.

Most are colourless or glass green tubular or applied base rings measuring $3.5-5 \mathrm{~cm}$. The remnants of the vessel wall were carefully trimmed off, but no traces of grozing or polishing could be observed. At the same time, traces of use-wear and scratches were visible on several fragments. The smaller pieces $(3.5-5 \mathrm{~cm})$ are particularly interesting since eighteen pieces are currently known from vicus of Intercisa, a fairly high number from a single settlement. Their roughly identical form and size would suggest a more or less similar function. It seems likely that they served a similar purpose as the roundels made from broken pottery sherds that were re-used as counters or gaming pieces, or possibly as lids for narrow-mouthed flasks. Curiously enough, some of the base rings had been cut/broken in half or quarter, quite obviously an indication of re-working. It is possible that these pieces had a different value than their intact counterparts in a board game.

One piece made from the thick base of a flask resembles the glass counters made domestically. Its upper part bears an incised X motif (Cat. no. 10, Fig. 2.4-5). This exemplar was in all likelihood used as a gaming piece, with the incised X marking its value. Its form is the exact counterpart of the cast glass counters, even though it was made from the fragment of a broken glass vessel. Another curious piece was made from the base of a square flask (IsINGs 50) with petal decoration (Cat. no. 9, Fig. 2.6-7), bearing scratch marks, which obviously originated from its secondary usage since these marks were on the inner side of the fragment. Although the function of this piece remains uncertain, its use as a vessel lid, a glass fermentation weight or a counter seems likely. The fragment was doubtless reused for some purpose since the edge of the flask's base fragment with the petal design was clearly worked to enable its further use. Another noteworthy piece is the separately blown ring base of a colourless chalice, which, similarly to the comparable pieces from Aquincum, had probably functioned as a cup (Cat. no. 22, Fig. 5.3-4).

One single fragment can be assigned to the type with a cutting edge, suggesting that it had been perhaps used in textile or leather working, or as a knife-like cutting tool in daily life (Cat. no. 20, Fig. 4.6-8). One particularly interesting trait of these fragments is that two cutting edges were

18 Fünfschilling 2015, 172; Chew 1988, Pl. 4.

19 FüleP 1984, Fig. 99, Grave 10.

20 FÜNFSCHILLING 2015, 174; Miller 1984. 


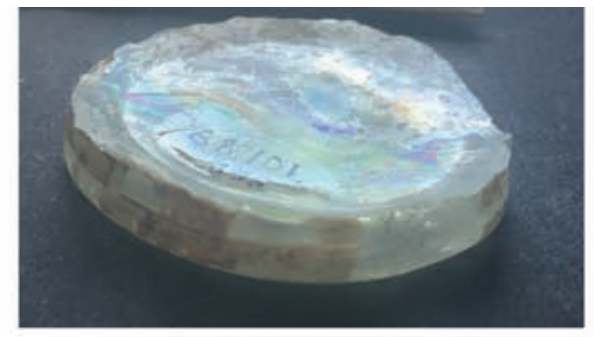

1

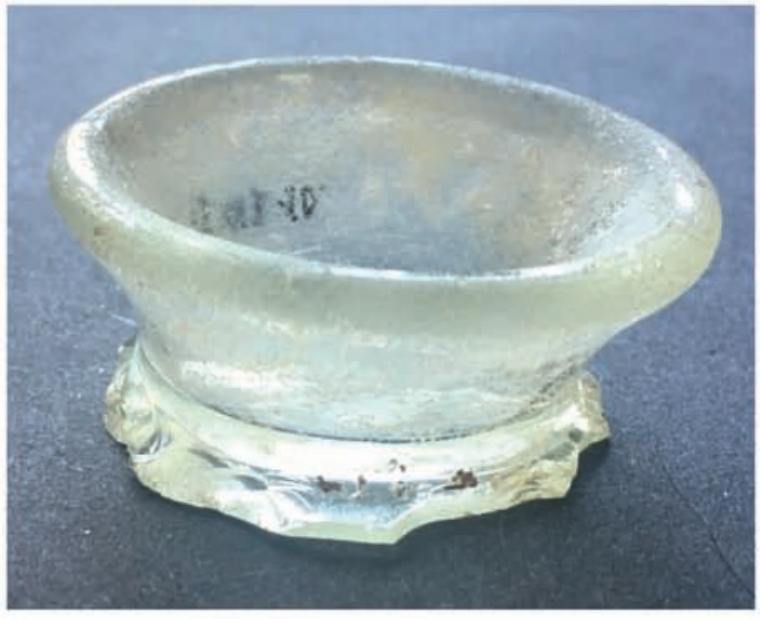

3

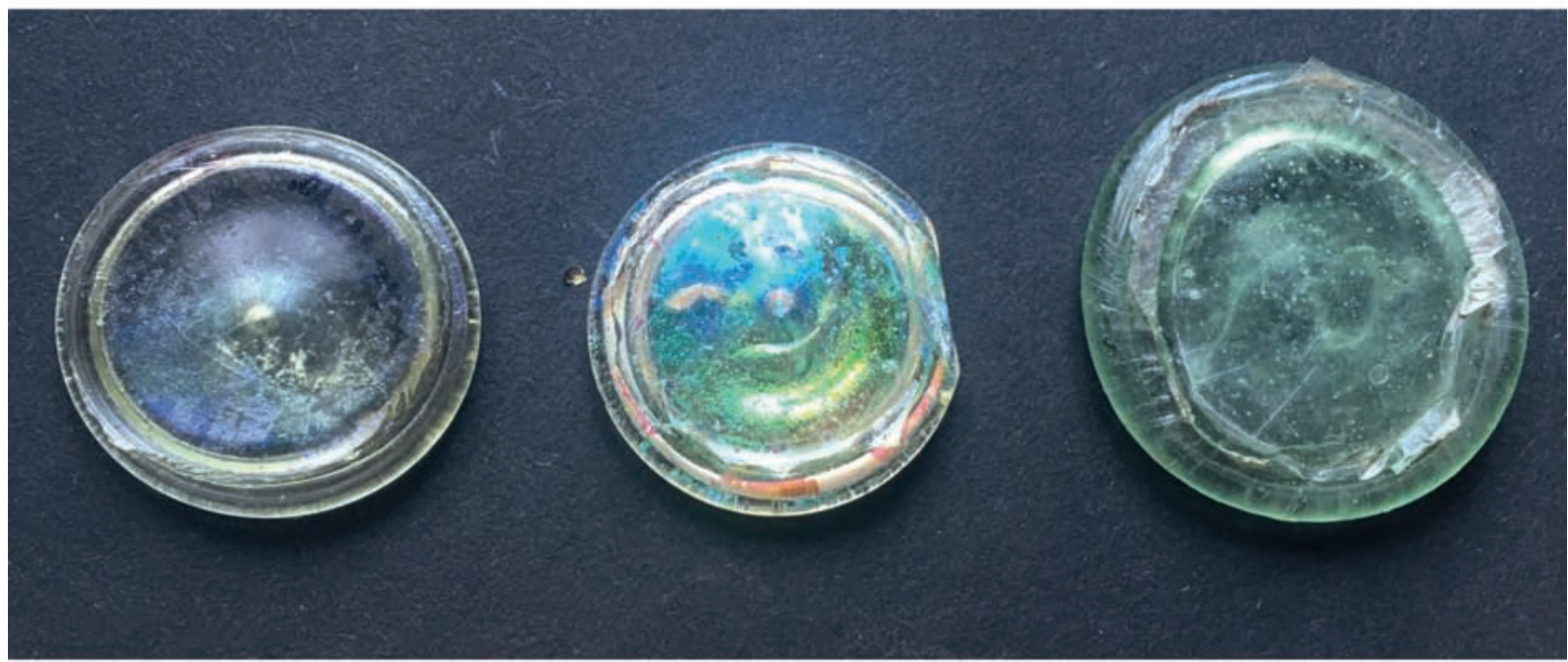

5

$1 \mathrm{~cm}$

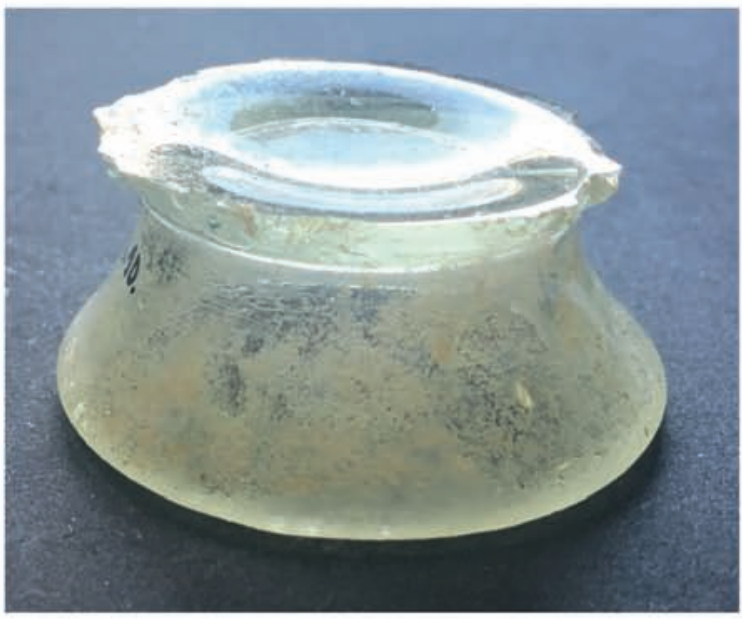

4

2 

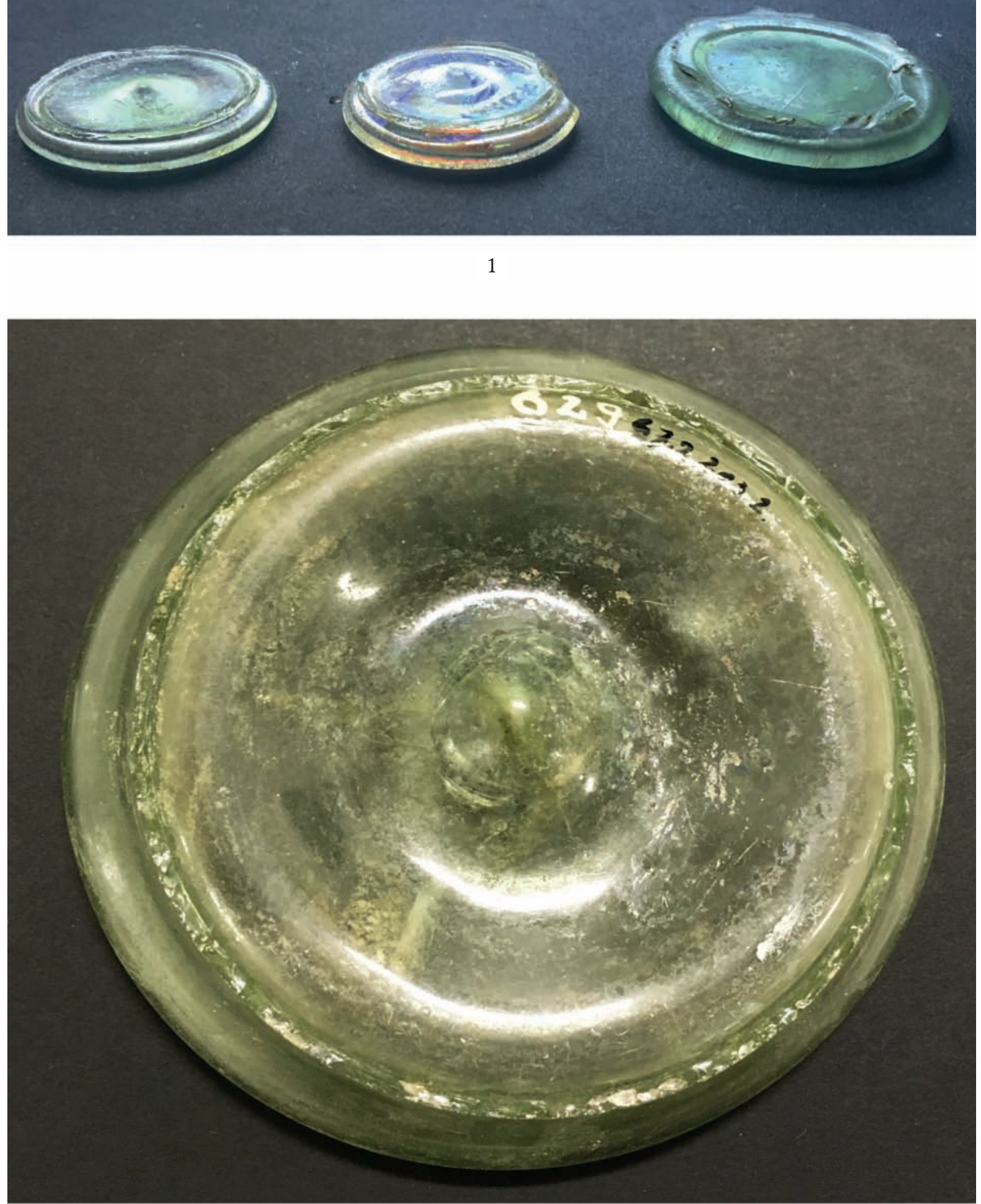

2

$1 \mathrm{~cm}$

Fig. 6. Re-Used Glass Fragments from Intercisa. 
made on these triangular glass shards and large flake scars can be made out on one edge that were formed when the fragment was repurposed into a tool. The other edge bears tiny nicks that are unrelated to the re-working procedure, but derive from their use (use-wear micro-flaking).

Finally, mention must be made of an assemblage of four pieces. Two of these are large tubular base rings, which in view of their sizes could have been used as lids, bowls or cosmetic palettes (Cat. nos 27-28, Fig. 6-8). The third is the base of a pipette-shaped unguent bottle found together with a small conical pot (Cat. no. 29, Fig. 8). The base fragment fits the mouth perfectly, suggesting that this glass base had been re-used as a stopper. These objects were found in a closed context, in one of the late Roman burials of Intercisa (Grave 629): they had been deposited in a child's coffin, near the right knee and legs. The burial attests to a similar custom as could be noted in Aquincum, ${ }^{21}$ where ring bases of bowls and flasks blown from a separate gather were deposited in burials as cups and bowls, a rather cost-efficient practice (six well-documented cases are known from Aquincum). Very often, these separately blown ring bases were placed in the grave upside-down, a clear indication of their new function, which could also be observed at Intercisa. All of the cited examples come from late Roman burials, dating from a period when people could perhaps no longer afford to deposit more expensive glass cups into burials. The child burial from Intercisa is outstanding in that it contained not one single ring base re-used as a cup, but a series.

Two other glass stoppers are known from Intercisa (Cat. no. 30-31, Fig. 9) Stoppers are infrequent finds of the Roman period; their identification as stoppers is based on formal analogies with stoppers used for closing narrow-mouthed flasks from the Early Modern Age. One good counterpart to one fragment is a stopper of identical form made in the 1870 s that came to light from the Thames. ${ }^{22}$ The other colourless stopper is topped by a sphere whose upper half is broken and incomplete, the lower half is a short cylindrical rod (Cat. no. 30, Fig. 9). Comparable metal stoppers were used for closing Roman-period aryballoi and unguentaria. ${ }^{23}$ It is questionable wheter it is Roman or Early Modern Age.

The over thirty re-used glass vessel fragments from Intercisa are noteworthy since they come from the find material of a single vicus. It seems likely that the repurposing of broken glass vessels was a more common practice than the currently available publications would suggest. In all likelihood, it made good sense to re-use the fragments of broken glass vessels either as simple domestic objects or as grave goods.

The perhaps most intriguing issue is what these ring bases with a diameter of 3-5 $\mathrm{cm}$ had been used for, particularly in view of the high number of both glass and ceramic pieces falling into this size category, which would suggest a by and large similar and most probably quotidian function. Their interpretation as counters or gaming pieces for board games is attractive, although their use as lids or fermentation weights seems equally feasible. Glass lids are very practical, being easily cleaned and having a substantial weight. A function as a fermentation weight when pickling or as lids for the storage or preservation of foodstuffs to prevent

21 DÉvai 2016.

22 https://thamesadmirer.wordpress.com/tales-of-glass-bottle-glass-finds-on-the-thames-foreshore/

23 https://ancientglass.wordpress.com/2012/02/08/roman-glass-aryballos-with-chain-stopper; https://research.britishmuseum.org/research/collection_online/collection_object_details.aspx?object$\mathrm{Id}=465092 \&$ partId=1

https://www.bmimages.com/preview.asp?image $=00219108001$ 
contact with air and spoiling is similarly feasible. This function was probably more common in historical periods than we would assume today.

The identification and publication of the glass fragments bearing clearly identifiable traces of secondary working and re-use recovered from well-documented archaeological contexts is a particularly important task. Doubly so, since this would offer an insight into the volume of reused Roman glass and provide important clues for the possible function(s) of the re-used glass.

\section{Catalogue of re-used glass vessel fragment from Intercisa}

1. Glass green closed tubular base ring with pontil scar. The remnants of the vessel wall were carefully trimmed off from the base ring. Diam: $3.5 \mathrm{~cm}$. Inv. no. 58.3.2.26. (Fig. 1.1).

2. Colourless base ring of thick trail applied to the underside, base mark, the remnants of the vessel wall were trimmed off, half broken. Diam: 4 cm. Inv. no. 74.28.480. (Fig. 1.2).

3. Colourless base ring of thick trail applied to the underside of the base, base mark, the remnants of the vessel wall were trimmed off, half broken. Diam: 4 cm. Inv. no. 74.28.476. (Fig. 1.3).

4. Glass green base ring of applied base trail, the remnants of the vessel wall were trimmed off, half broken. Diam: 5.5 cm. Inv. no.: 76.46.88. (Fig.1. 4-5).

5. Glass green base ring of applied base trail, the remnants of the vessel wall were trimmed off. Diam: 5 cm. Inv. no.: 76.46.86. (Fig. 1. 6-7).

6. Glass green base ring of applied trail, the remnants of the vessel wall were trimmed off, pontil scar. Diam: 5 cm. Inv. no.: 77.5.4. (Fig.1. 8-9).

7. Glass green base ring of applied trail, the remnants of the vessel wall were trimmed off, pontil scar. Diam: $4.5 \mathrm{~cm}$. Inv. no.: 77.2.14. (Fig. 2.1-2).

8. Colourless base ring of thick trail applied to the underside of the base, base mark, the remnants of the vessel wall were trimmed off, half broken. Diam: $4 \mathrm{~cm}$. Inv. no.: 75.126.1. (Fig. 2.3).

9. Glass green base fragments of a bottle (IsINGS 50) with tooling marks of petals set in a circle, the remnants of the vessel wall were trimmed off. Diam: 8,5 cm Inv. no. 74.28.29. (Fig. 2.6-7).

10. Fragment of a green glass solid vessel base with an engraved X-shaped motif on top. Concave, trimmed edges. $2 \times 1.6 \mathrm{~cm}$. Inv. no. 74.28.29. (Fig. 2.4-5).

11. Glass green base fragment of bottle, trimmed edges, flat base fragment. Diam: $4.5 \mathrm{~cm}$. Inv. no. 91.430.1. (Fig. 3.1).

12. Colourless base ring of thick trail applied to the underside of the base, base mark, the remnants of the vessel wall were trimmed off. Diam: $6 \mathrm{~cm}$. Inv. no. 91.430.1. (Fig. 3.4).

13. Colourless base ring ofthick trail applied to the underside of the base, base mark, the remnants of the vessel wall were trimmed off. Diam: $4.5 \mathrm{~cm}$. Inv. no. 91.430.1. (Fig. 3.2).

14. Colourless base ring of thick trail applied to the underside of the base, the remnants of the vessel wall were trimmed off. Diam: $2.4 \mathrm{~cm}$. Inv. no. 91.423.1. (Fig. 3.3, 5).

15. Colourless base ring of thick trail applied to the underside of the base, the remnants of the vessel wall were trimmed off. Diam: $4 \mathrm{~cm}$. Inv. no. 91.423.1. (Fig. 3.6).

16. Glass green rim fragment of a bottle. Fire-rounded rim and double horizontal trail under the rim. Trimmed, ring-shaped fragment. Diam: $3.8 \mathrm{~cm}$. Inv. no. 91.501.1. (Fig. 3.7).

17. Glass green base fragment of applied trail, the remnants of the vessel wall were trimmed off, pontil scar. Diam: 5.5 cm Inv. no. 91.372.1. (Fig. 4.1-2).

18. Glass green base fragment of applied trail, the remnants of the vessel wall were trimmed off, broken into a quarter-circle. $2.5 \times 2.5 \mathrm{~cm}$. Inv. no. 68.101.198. (Fig. 4.3).

19. Glass green base fragment by applied trail, the remnants of the vessel wall were trimmed off, broken into a quarter-circle. $2.2 \times 2.4 \mathrm{~cm}$. Inv. no. 2000.21.16. (Fig. 4.4).

20. Glass green vessel fragment. Triangular flake, trimmed. Inv. no. 68.101.282. (Fig. 4.6-8).

21. Colourless base fragment of applied trail, the remnants of the vessel wall were trimmed off, pontil scar. Inv. Diam: 4 cm. no. 68.101.398. (Fig. 5.1-2). 
22. Colourless fragmet of the separately blown foot of a cylindrical beaker, the remnants of the vessel wall were trimmed off. Diam: 8 cm. Inv. no. 75.113.12. (Fig. 5.3-4).

23. Colourless concave base, the remnants of the vessel wall were trimmed off, pontil scar. Diam: $4 \mathrm{~cm}$. Inv. no. 75.113.10. (Fig. 5.5, Fig. 6.1).

24. Colourless concave base with closed tubular base edges, the remnants of the vessel wall were trimmed off, pontil scar. Diam: 4.5 cm. Inv. no. 75.113.10. (Fig. 5.5, Fig. 6.1).

25. Glass green concave base with closed tubular base edges, the remnants of the vessel wall were trimmed off, pontil scar. Diam: 4.8 cm. Inv. no. 75.113.10. (Fig. 5.5, Fig. 6.1).

26. Glass green tubular base ring, pontil scar, the remnants of the vessel wall were trimmed off. Diam: 10.5 cm. Inv. no. 67.2.203.2. (Fig. 6.2, Fig. 7.1).

27. Glass green flat, tubular base, pontil scar, the remnants of the vessel wall were trimmed off. Diam: 13.2 cm. Inv. no. 67.203.1. (Fig. 7.2, Fig. 8.1-2).

28. Colourless solid, rounded base of a long, narrow, pipette-shaped unguent bottle. Diam: $1.6 \mathrm{~cm}$. Inv. no. 67.203.4. (Fig. 9.1-2).

29. Glass green conical stopper. Hole in the middle. $1.8 \times 2.5 \mathrm{~cm}$. Inv. no. 74.24.496. (Fig. 9.3-4).

30. Colourless stopper. Solid elongated rod topped by a solid sphere, upper end broke off. $1.2 \times 3.5 \mathrm{~cm}$. Use-wear scratch marks on the neck. Roman? Inv. no. 95.7.104. (Fig. 9.5-6).

\section{References}

Addyman, P. V. - Priestley, J. 1977: Baile Hill, York. Archaeological fournal 134, 115-156.

Chew, H. 1988: La tombe gallo-romaine de Saintes. Antiquités Nationales 20, 35-61.

Cosyns, P. 2015: Beyond the Channel! That's Quite a Different Matter: A Comparison of Roman Black Glass From Britannia, Gallia Belgica And Germania Inferior. In: BAyley, J. - Freestone, I. JACKson, C. (eds): Glass of the Roman World. Oxford 2015, 190-204.

Crummy, N. 1983: The Roman small finds from excavations in Colchester 1971-1979. Colchester Archaeological Reports 2.

DÉvaI, K. 2016: Secondary use of base rings as drinking vessels in Aquincum. Dissertationes Archaeologicae 3/4, 135-144.

FÜLEP, F. 1984: Sopianae: The history of Pécs during the Roman era, and the problem of the continuity of the late Roman population. Budapest.

Fünfschilling, S. 2015: The re-use of Roman glass fragments. In: BAyley, J. - Freestone, I. - JAcKson, C. (eds): Glass of the Roman Word. Oxford 2015, 170-178.

IsINGS, C. 1957: Roman Glass from dated finds. Groeningen/Djakarta 1957.

MacGregor, A. 1978: Roman finds from Skeldergate and Bishophill. The Archaeology of York 17/2.

Miller, R. 1984: Flaked stone manufacture and use at Busra from the Epipalaeolithic to early Islamic times. Berytus 32, 149-158.

Price, J. 1985: The glass. In: Bidwell, P. T. (ed.): The Roman Fort of Vindolanda, Northumberland. Historic Buildings and Monuments Commission for England (Archaeological Report 1). London 1985, 206-214.

B. VÁGÓ, E. - BóNA, I. 1976: Die Gräberfeld von Intercisa. Der spätrömische Südostfriedhof. Budapest.

Zsıdi, P. 1984: A Kaszás Dúloo-Raktárréti római kori temető elemzése. Budapest 1984. Doktori disszertáció. Kézirat.

\section{Sources}

Pliny NH: Caius Plinius Secundus: Naturalis Historia. 

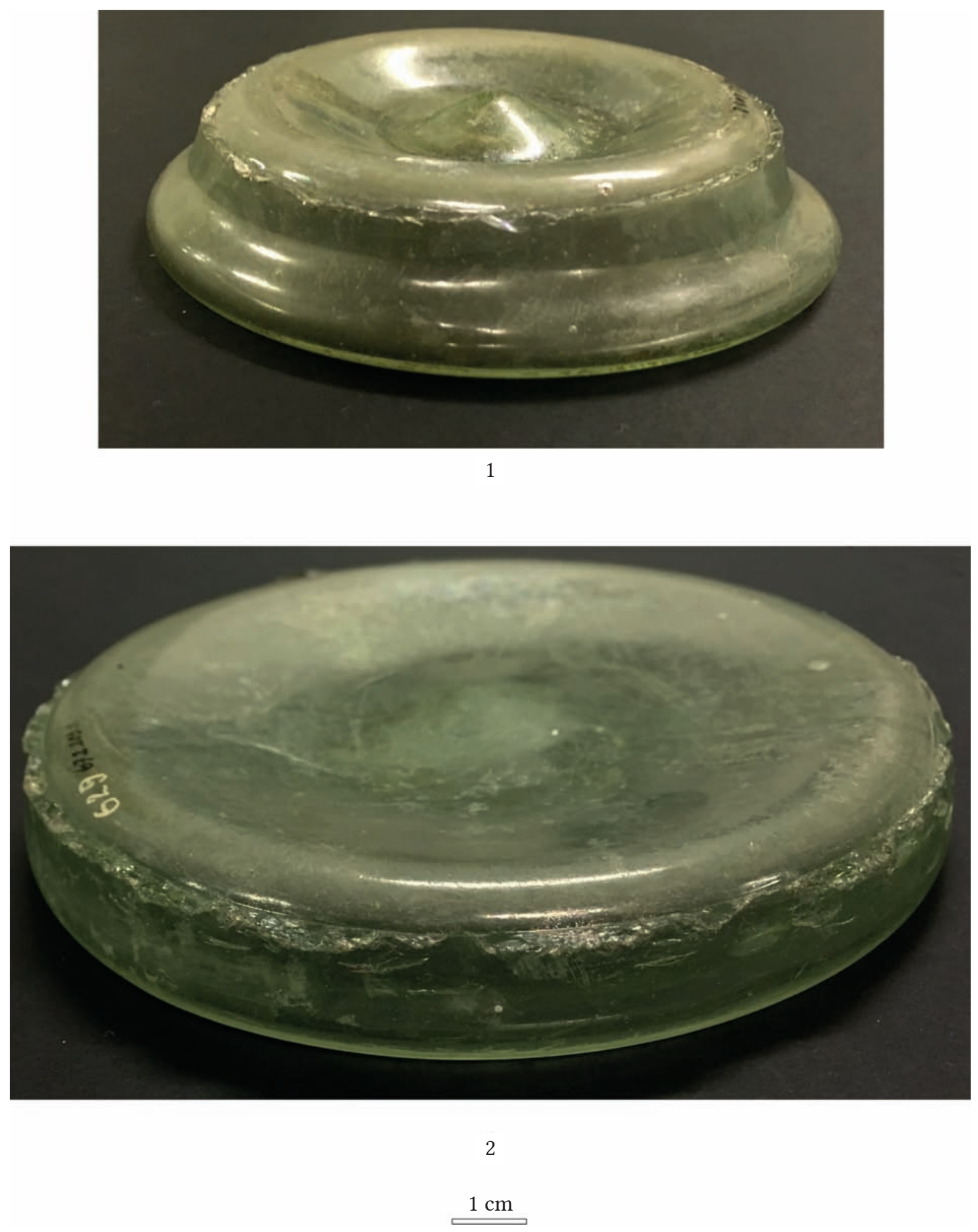

Fig. 7. Re-Used Glass Fragments from Intercisa. 

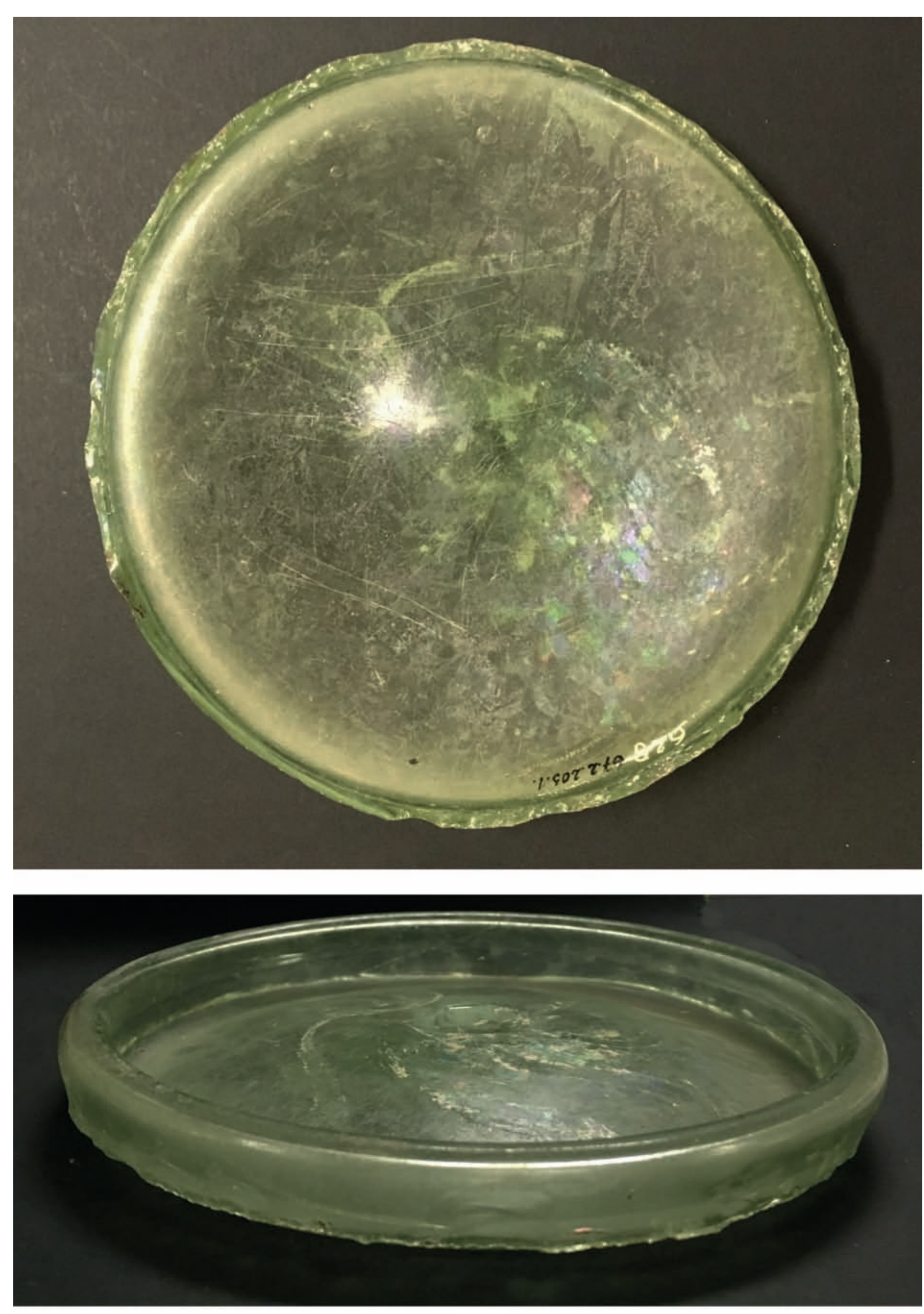

$1-2$

$1 \mathrm{~cm}$

Fig. 8. Re-Used Glass Fragments from Intercisa. 

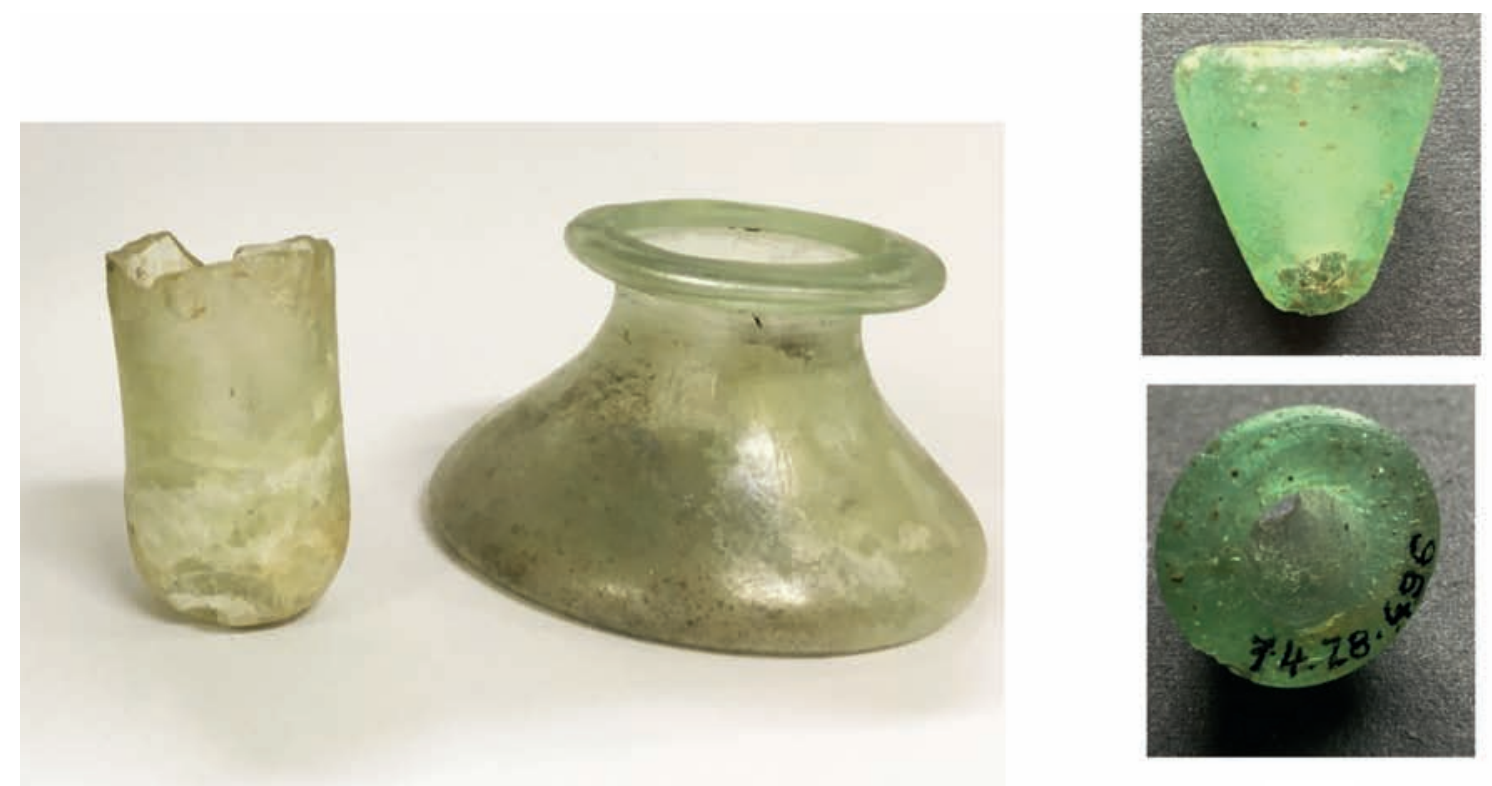

3-4

1
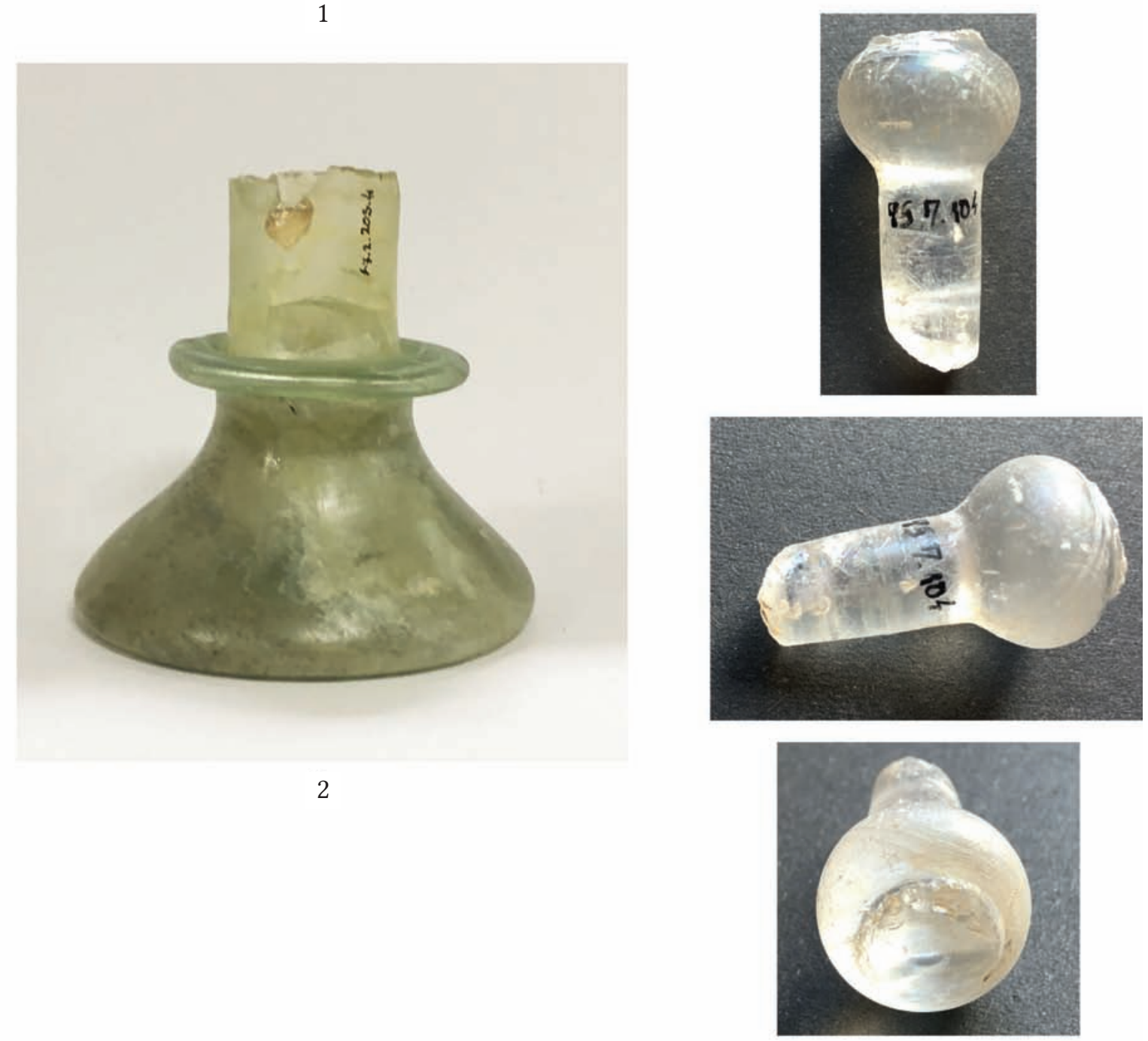

$1 \mathrm{~cm}$

5-7

Fig. 9. Re-Used Glass Fragments from Intercisa. 


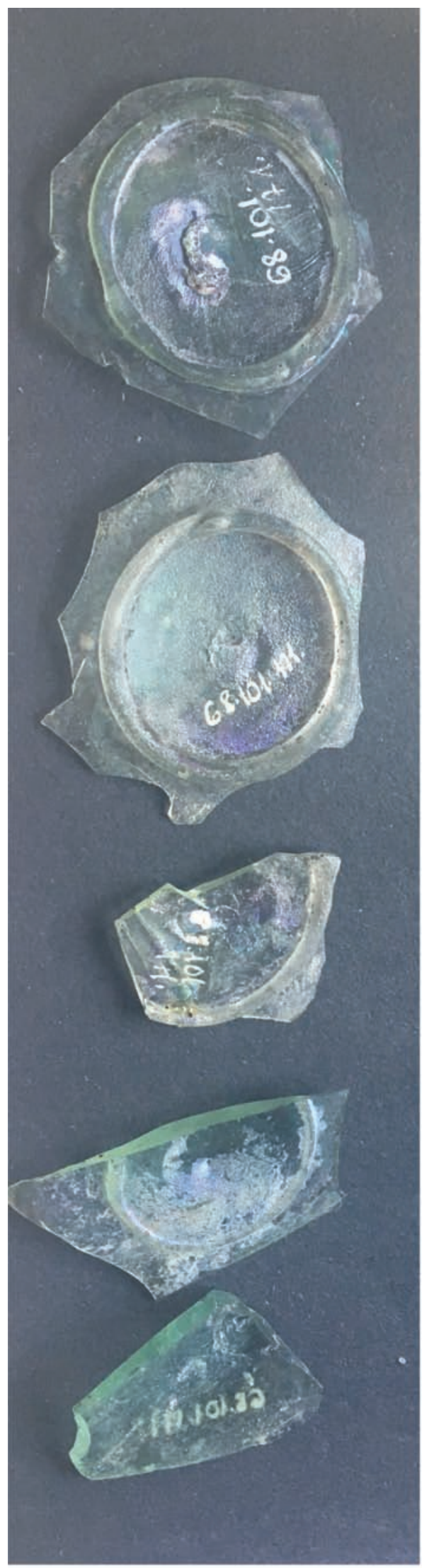

1
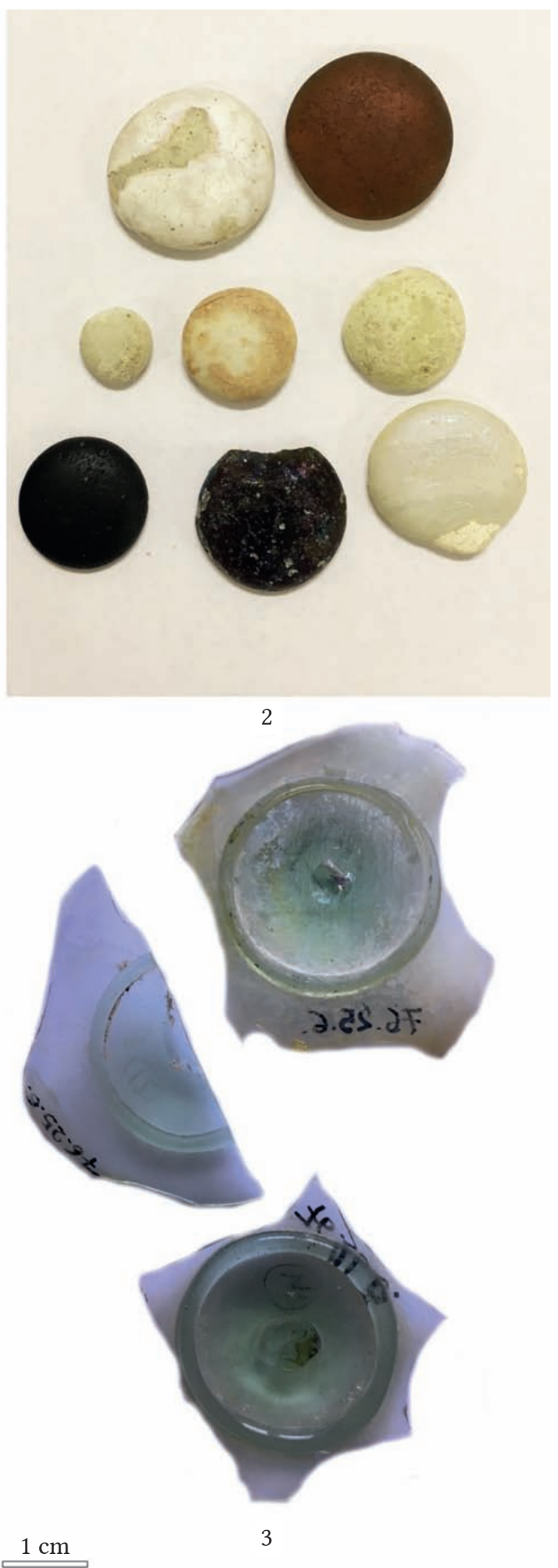

Fig. 10. Re-Used Glass Fragments from Intercisa. 


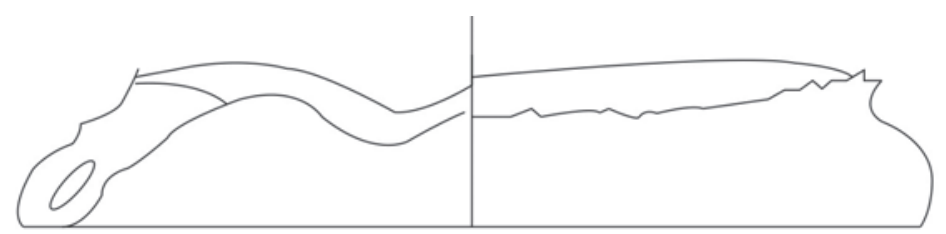

1

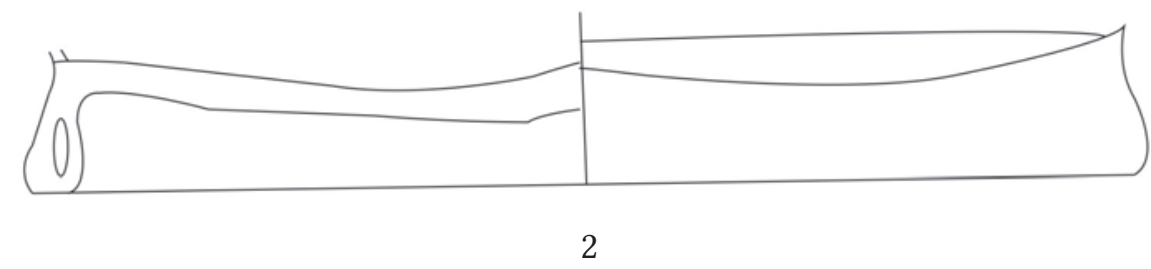

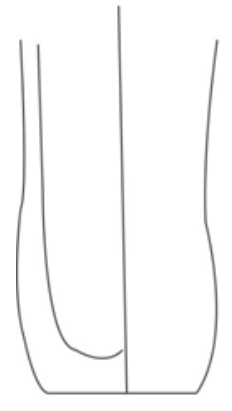

3 .

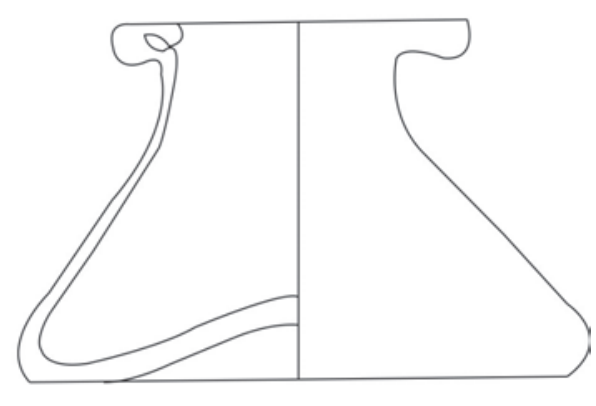

4 .

Fig. 11. Re-Used Glass Fragments from Intercisa.

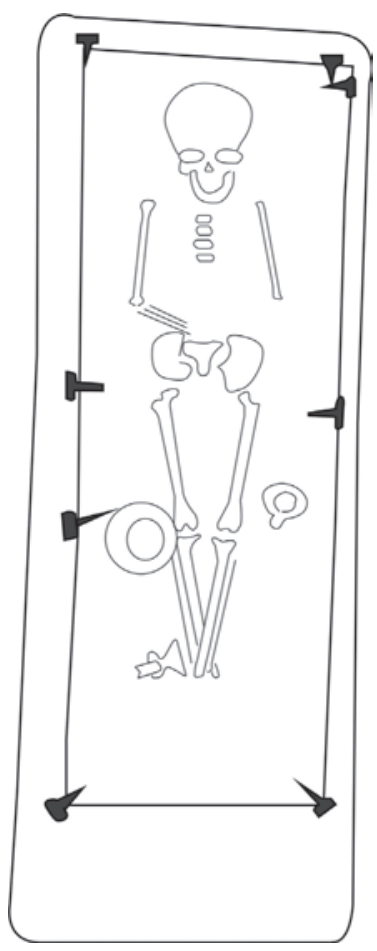

Fig. 12. Late Roman burial from Intercisa, Grave 629. (Based on B. VÁGÓ - BóNA 1976). 